\title{
Life cycle assessment of intensive striped catfish farming in the Mekong Delta for screening hotspots as input to environmental policy and research agenda
}

\author{
Roel Bosma • Pham Thi Anh • José Potting
}

Received: 11 January 2011 / Accepted: 12 July 2011 / Published online: 10 August 2011

(C) The Author(s) 2011. This article is published with open access at Springerlink.com

\begin{abstract}
Purpose Intensive striped catfish production in the Mekong Delta has, in recent years, raised environmental concerns. We conducted a stakeholder-based screening life cycle assessment (LCA) of the intensive farming system to determine the critical environmental impact and their causative processes in producing striped catfish. Additional to the LCA, we assessed water use and flooding hazards in the Mekong Delta.

Materials and methods The goal and scope of the LCA were defined in a stakeholder workshop. It was decided there to include all processes up to the exit-gate of the fish farm in the inventory and to focus life cycle impact assessment on global warming, acidification, eutrophication, human toxicity, and marine (MAET) and freshwater aquatic ecotoxicity (FWET). A survey was used to collect primary inventory data from 28 farms on fish grow-out, and from seven feed mills. Hatching and nursing of striped catfish fingerlings were not included in the assessment due to limited data availability and low estimated impact.
\end{abstract}

Responsible editor: Seungdo Kim

R. Bosma $(\bowtie)$

Aquaculture and Fisheries, Wageningen University,

Marijkeweg 40,

6709PG Wageningen, The Netherlands

e-mail: roel.bosma@wur.nl

P. T. Anh

Department of Environmental Technology and Management,

Van Lang University,

Ho Chi Minh, Vietnam

J. Potting

Environmental Systems Analysis, Wageningen University,

Droevendaalsesteeg 4,

6708PB Wageningen, The Netherlands
Average feed composition for all farms had to be applied due to limitation of budget and data availability.

Results and discussion Feed ingredient production, transport and milling dominated most of the impact categories in the LCA except for eutrophication and FWET. Most feed ingredients were produced outside Vietnam, and the impact of transport was important. Because of the screening character of this LCA, generic instead of specific inventory data were used for modelling feed ingredient production. However, the use of generic data is unlikely to have affected the main findings, given the dominance of feed production in all impact categories. Of the feed ingredients, rice bran contributed the most to global warming and acidification, while wheat bran contributed the most to eutrophication. The dominance of both was mainly due to the amounts used. Fishmeal production, transport and energy contributed the most to MAET. The biggest impacts of grow-out farming in Vietnam are on eutrophication and FWET. Water nutrient discharge from grow-out farming was high but negligible compared with the natural nutrient content of the Mekong River. The discharge from all growout farms together hardly modified river water quality compared with that before sector expansion.

Conclusions Feed production, i.e. ingredient production and transport and milling, remains the main contributor to most impact categories. It contributes indirectly to eutrophication and FWET through the pond effluents. The environmental impact of Pangasius grow-out farming can be reduced by effectively managing sludge and by using feeds with lower feed conversion ratio and lower content of fishery products in the feed. To consider farm variability, a next LCA of aquaculture should enlist closer collaboration from several feed-milling companies and sample farms using their feeds. Future LCAs should also preferably collect specific instead of generic inventory data for feed 
ingredient production, and include biodiversity and primary production as impact categories.

Keywords Aquaculture - Environmental impact - LCA . Pangasius $\cdot$ Striped catfish $\cdot$ Vietnam

\section{Introduction}

In the past, farmers in the Mekong Delta used to grow catfish in cages and in extensively managed ponds on small integrated farms. The cages were stocked with Pangasius bocourti, while the ponds were stocked with striped catfish (Pangasianodon hypophthalmus). In those days, fish grown in ponds was intended for private consumption and local markets. Since 2002, however, pond culture has been intensified to increase production for export (Lam et al. 2009). The financial margin of raising striped catfish in intensive ponds is better because less feed is spoiled in ponds than in cages where non-ingested feed is carried away by the river flow. Also, it is relatively easy to artificially reproduce, hatch, and nurse $P$. hypophthalmus. The increase in pond production is reflected in a shift in the species farmed (Fig. 1).

The development of intensive grow-out-farms has been accompanied by an explosive growth in hatcheries, nurseries, feed-mills, input providers, factories producing frozen fillets, export companies and certification bodies in Vietnam and repacking facilities in the importing countries. At present, so-called vertical market-chain integration is occurring. A large share of the increased production has been achieved thanks to non-farmers investing in very large ponds (see Table 1 for the trend in farm size). Most farms have several ponds, and some companies own several farms. The density of striped catfish in ponds of 2 to $4 \mathrm{~m}$ deep is 30 to $90 \mathrm{~kg} / \mathrm{m}^{2}$ prior to harvest, which is roughly equivalent to 15 to $25 \mathrm{fish} / \mathrm{m}^{3}$ (Lam et al. 2009).

Between 2002 and 2008, catfish production in the Mekong Delta increased eightfold, from 0.15 to about 1.2 million tonnes per year. This expansion was accompanied by increased resource use and environmental pressure, leading to non-governmental organisations and international press expressing their concern about the use of chemicals, the water pollution and biodiversity degradation (Bush et al. 2009). In 2009, the Vietnamese government addressed these concerns in a 2020 Master Plan for the Pangasius production sector in the Mekong delta. This paper reports the environmental impact assessment (EIA) supporting implementation of this 2020 Master Plan.

Various existing EIA methods complement each other by covering different aspects (Bartley et al. 2007). Life cycle assessment (LCA) is an EIA method that systematically evaluates the environmental aspects of a product's life cycle (from resource extraction, through all subsequent processes involved in production, up to the end of the product's lifetime). LCA can be used to identify dominant environmental issues in a product's life cycle and to set priorities for policy interventions. The EIA described here employed LCA for this purpose and complemented it with an assessment of water use and quality, and of flooding hazards.

The next section describes the methods used for the EIA. Section 3 provides the results of the life cycle inventory analysis. Section 4 presents the outcome of the life cycle impact assessment and of the impact categories assessed in addition to the LCA. Section 5 reflects on the quality of the results before drawing main conclusions and identifying mitigation strategies.

\section{Methods-goal and scoping}

The EIA of the catfish sector in the Mekong Delta was carried out parallel to the four main phases in the standardised LCA procedure (ISO 2006):

Goal and scoping workshop with stakeholders and study team-defining the purpose and methodological specifications of the study;

Pangasius production systems

Fig. 1 Production of Pangasius in the Mekong Delta in latrine ponds, cages and intensive ponds (left $Y$-axis; shaded areas). Originally, both $P$. bocourti and $P$. hypophthalmus were produced, but the share of the last (dots) gradually increased (based on Nguyen et al. 2008)

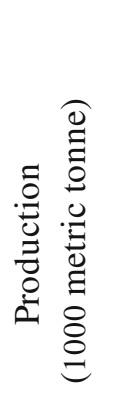

1999

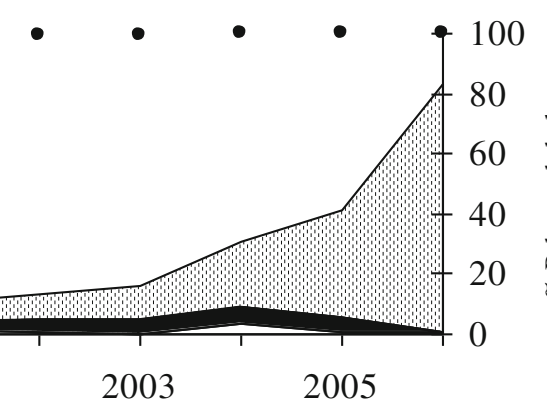

200 
Table 1 The evolution of the size distribution of striped catfish farms (\%) based on Nhi (2005) and Nguyen et al. (2008)

\begin{tabular}{lllll}
\hline Year & Total estimated area (ha) & \multicolumn{3}{l}{ Percentage of farms by size category } \\
\cline { 3 - 5 } & & Small $(0.035-0.1$ ha $)$ & Medium $(0.1-0.3$ ha $)$ & Large $(>0.3$ ha) \\
\hline 2004 & 3,000 & 17 & 33 & 30 \\
2007 & $10,000^{\text {a }}$ & 10 & 30 & 60 \\
\hline
\end{tabular}

${ }^{a}$ This includes probably the nurseries; other sources indicate approximately 6,000 ha was used for grow-out and that in $200915 \%$ only of the grow-out farms were less than 1 ha in size

Inventory analysis by the study team-data collection and modelling of all inputs and outputs of the processes making up a product system;

Impact assessment by the study team - translating inventory data into their contribution to a wide range of impact categories;

Interpretation by the study team and through stakeholder discussions - evaluating quality of data and results, to draw conclusions relating to the study's goal and scope.

Goal and scope definition is a crucial phase in LCA. If well done, the other phases are basically a matter of following the method specified. Note that in practice, however, performing an LCA is typically an iterative process. That is, all phases may have to be passed through more than once in response to new demands posed by a later phase.

The goal and initial scoping for the EIA were defined in a workshop with around 30 stakeholders, mainly from government institutions, on 25 August 2008, in Ho Chi Minh city. The stakeholder workshop confirmed that the EIA of the sector was needed for the following reasons:

- International concern about environmental impacts (Bush et al. 2009),

- Regional problems of safe drinking water provision,

- Regional concern about sustainability of the producers' livelihoods, and

- Vietnam's desire for strategic policy-making.

The goal defined for this study was to determine the critical environmental impacts and processes in the production of striped catfish in intensive farming systems. Knowledge about those critical impacts and processes was considered indispensible for priority-setting of mitigation or reduction options in research and policy-making.

The workshop resulted in a general description of the catfish production system and sub-systems (Fig. 2). The stakeholders used three arguments to set the boundary for the EIA at the exit-gate of the Pangasius grow-out farm: (1) regulations for the processing industry are well-defined, (2) technologies for mitigating environmental impacts by processors are available, (3) and the processing of the product after it leaves the farm is controlled by other authorities (provincial agencies for environment and food safety). The LCA described in this paper therefore stopped at the farm exit-gate and did not include processes further downstream.

In the days following the workshop, the study team further refined the resulting cradle-to-gate assessment so that it focused on pond farming and excluded production in cages, fences, and nets as these systems have become relatively unimportant (see Fig. 1). Extensive pond production of fresh catfish for local markets has also become of minor importance and was therefore not considered separately. Home-made feed was excluded because this sub-system is difficult to quantify and less than $10 \%$ of the farmers regularly used such feed (Lam et al. 2009). The functional unit for this study was set at one metric ton $(1,000 \mathrm{~kg})$ of fresh fish at the farm's exit-gate (ready for delivery).

Inventory analysis in LCA, i.e. life cycle inventory (LCI) analysis, quantifies the cradle-to-gate inputs and outputs of the production processes in the product system (see Fig. 2). The study team decided to use a questionnaire to collect primary data about grow-out farming and feed-milling and to extract other data from the EcoInvent ${ }^{\circledR} 2.0$ database and from related research projects managed by team members and from the literature. The quality requirements for data collection were set according to type and importance of the

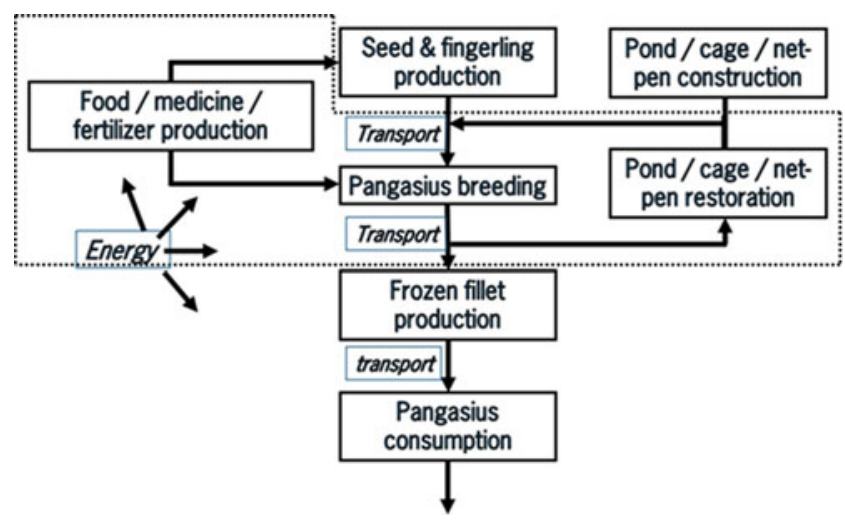

Fig. 2 An overview of the Pangasius production system and the boundary (dotted line) for the life cycle assessment 
processes involved (Goedkoop et al. 2008) adapted from Weidema and Wesnaes (1996).

Impact assessment in LCA, i.e. life cycle impact assessment (LCIA), quantifies the contribution of the inventory data to a number of environmental impact categories. The stakeholder workshop selected the following subset of the usual LCA impact categories as relevant for this EIA: global warming, acidification, eutrophication, toxicity, and energy. The assessment methods for global warming (GW) and acidification (AC) were taken from Hauschild and Potting (2005) and for aquatic eutrophication from Guinée (2002). Human toxicity (HT), freshwater (FWET) and marine aquatic ecotoxicity (MAET) were assessed according to Rosenbaum et al. (2008). Terrestrial ecotoxicity was not covered because of the absence of good-quality impact factors (Hauschild 2008). Energy depletion was calculated by totalling the use of primary energy.

The impact categories selected largely coincided with those proposed for seafood LCAs by Pelletier et al. (2007). The study team left out photochemical oxidant formation as they considered this to be a non-issue in the Mekong Delta. Ozone depletion was excluded because, following Hauschild and Wenzel (1998), this was considered to be a disappearing problem thanks to control measures taken since enforcement of the Montreal-Protocol in 1987. Land use and net primary production as indicators for food security and biotic resource depletion were considered as less relevant for the Mekong Delta, the region which was the focus of the EIA for which this screening LCA was used.

The stakeholders mentioned four impact categories of interest in addition to the LCA: land use and its biodiversity consequences, water use and depletion, water quality, and flooding hazards. The assessment results for three of these impact categories are reported separately. Water quality is not addressed separately, as some of its detrimental effects are covered by eutrophication and aquatic toxicity in LCIA. Land use and aquatic and terrestrial biodiversity were addressed but are not reported in detail this paper. The methodology for biodiversity assessment in LCA is still weak (Curran et al. 2010), and this affects the relevance of results for these categories of impact.

As this EIA had limited budget and time at its disposal, it focused on the main processes and impacts. Above we noted that the stakeholders and study team excluded few processes and impacts considered as less important or relevant, and average data were used for some processes. This is in line with SETAC guidelines for screening LCAs (Christiansen 1997; Todd and Curran 1999) and complies with ISO 14044 (2006). In accordance with this ISO, the interpretation phase evaluated the possible influence on the inventory and impact assessment before conclusions were drawn in relation to the goal of our LCA. After preliminary interpretation by the study team, the inventory and impact assessment results were presented and discussed at several stakeholder workshops. The main workshop, held on 21 May 2009 in Can Tho city, attracted around 60 Vietnamese participants from the sector. On other occasions, such as a bilateral meeting of Vietnamese and Dutch representatives on 8 July 2009 in Ho Chi Minh City, the conclusions and recommendations were discussed with policymakers.

\section{Results-LCI analysis}

\subsection{Grow-out farming}

Primary data on farms were collected by administering a questionnaire to the owners of 28 grow-out farms selected by staff of the Departments of Fisheries Resource Protection and Management of Can Tho City and of Vinh Long province in the four major catfish-culturing areas. The completed questionnaires were checked by the local authorities of Can Tho, An Giang, Dong Thap and Vinh Long provinces. The survey yielded primary data on pond area, culture periods, pond preparation, stocking, feed use, water management and use of other inputs such as electricity, fuel, chemicals and medicines (Table 2).

The survey did not cover the feed brands used; later verification revealed that several farmers used different brands during one production cycle. As a result, the feed conversion ratio (FCR) for several individual farms could not be related to a specific feed used. This made it less relevant to include this variability in the further calculations. We therefore used the averages specified in Table 2 as input from upstream processes.

The 28 farms achieved an average yield of close to $300 \mathrm{t} /$ ha of harvested fish, with a mean FCR of 1.86 (see Table 2). Mortality rates varied from $16 \%$ to $23 \%$ (discounted in the calculations). To prepare the grow-out ponds, most farmers applied lime at an average rate of about $5 \mathrm{~kg} / \mathrm{t}$ fish

Table 2 Survey results for 28 catfish farms (mean \pm standard deviation)

\begin{tabular}{lll}
\hline Item & Unit & All farms \\
\hline Pond area & ha & $3.4 \pm 3.0$ \\
Fish production & Ton ha $^{-1}$ year $^{-1}$ & $427 \pm 273$ \\
Feed consumed & $1000 \mathrm{ha}^{-1}$ year $^{-1}$ & $0.81 \pm 0.53$ \\
FCR & $\mathrm{kg} / \mathrm{kg}^{-1}$ & $1.86 \pm 0.28$ \\
Electricity use & $\mathrm{kWh} \mathrm{t}^{-1}$ fish & $41 \pm 40$ \\
Diesel use & $1 \mathrm{f}^{-1}$ fish & $5 \pm 9$ \\
Lime use & $\mathrm{kg} \mathrm{t}^{-1}$ fish & $5.2 \pm 5.9$ \\
Chemical use & $\mathrm{kg} \mathrm{t}^{-1}$ fish & $0.12 \pm 0.17$ \\
\hline
\end{tabular}


produced. They used more than $1 \mathrm{~kg}$ of other products per ton fish produced (see next section).

LCI data for fish seed and fingerling production are not reported in this paper as these are negligible compared with grow-out farming and because data were not available on the nutrient content of the effluent water. Note that fish densities in the hatcheries and fingerling nurseries were low and overall this process in the production system used less than $0.5 \%$ of the biomass input used in the grow-out farms.

\subsection{Feed production}

A questionnaire was send to seven of the over 30 feed-mills in the south of Vietnam to obtain primary data about feed manufacturing. Three feed-milling companies supplied all the information requested. By using all the data supplied by the seven feed-mills, we were able to calculate the average feed composition (Table 3). Five feed-mills specified water and energy use and some parameters of the catfish feed. The ingredients for catfish feed came from 14 countries all over the globe. The ingredients imported were generally those of high quality (e.g. minerals, vitamins and soybean). Fishmeal and fish oil came from various Asian countries, including Vietnam, and originated both from inland and marine catches. The average Fish-In Fish-Out ratio (FIFO) of the seven feeds was 1.34 and ranged between 0.7 and 2.6. The FIFO-ratio indicates the proportion of fishery products used in the feed.

The feed-mills used $0.32 \mathrm{kWh}$ of electricity and 0.041 of diesel per $\mathrm{kg}$ feed produced. The water consumption given was $0.021 / \mathrm{kg}^{-1}$ feed.

With the exception of the rice-based ingredients, the LCI data for the production of feed ingredients came from databases such as Eco-Invent ${ }^{\circledR} 2.0$ and LCA Food DK, both provided by Simapro (Goedkoop et al. 2008). As our purpose was screening, we deemed it too time-consuming to exhaustively collect regional inventory data on feed ingredient production. Moreover, the available survey data did not allow us to collect inventory data on feed ingredients according to production locations because (1) the individual farms used feed from one to four different suppliers, (2) the farms surveyed used 19 different brands of feed, while (3) only three feed-mills provided complete data and (4) the feed-mills sourced ingredients from a range of locations which varied between and within years (rice bran was sourced from India, Thailand and Vietnam; broken rice from Vietnam only). We modelled rice ingredients on the basis of paddy rice produced in the Mekong Delta, assuming 10\% rice bran, 3\% rice meal and $9 \%$ broken rice as by-products (FAO 1972). The use of ricebased ingredients for catfish production in the Mekong Delta has no identifiable effect on any other production system except in terms of market price and reducing the waste of rice bran. This makes it difficult to avoid allocation by system expansion because there is no other system to expand with. Where system expansion is not an option, ISO 140440 (2006) recommends allocation based on physical relationships, e.g. mass allocation above energy and economic allocation. The latter is also less relevant because prices vary between and within years. We therefore applied mass allocation. The average rice yield in the Mekong Delta was $5.5 \mathrm{t} / \mathrm{ha}$ harvested crop, with the following inputs per hectare $-95 \mathrm{~kg} \mathrm{~N}, 55 \mathrm{~kg}$ P and $46 \mathrm{~kg} \mathrm{~K}$ in artificial fertiliser; 16.71 diesel; and $2 \mathrm{~kg}$ pesticides (inorganic chemicals; CTU/ Department of Plant Science (Phong et al. 2011)). Rice in the Mekong Delta is cropped two or three times a year, mostly from irrigated fields.

\subsection{Energy and transport}

Diesel is mainly used for transport of inputs, and on farms and in feed-mills to power generators, pumps or engines.
Table 3 Catfish feed composition (\%) of three feed mills separately and four other companies together (estimated averages) in the Mekong Delta

Swiss Switzerland, Others vitamins, minerals, antioxydants, inorganics

\begin{tabular}{|c|c|c|c|c|c|}
\hline \multirow[t]{2}{*}{ Ingredient } & \multirow[t]{2}{*}{ Countries of origin } & \multicolumn{4}{|c|}{ Feed company } \\
\hline & & A & $\mathrm{B}, \mathrm{C}, \mathrm{D}, \mathrm{E}$ & $\mathrm{F}$ & G \\
\hline Fish meal & Vietnam, Indonesia, India, Myanmar & 12.0 & 12.8 & 8.5 & 26.0 \\
\hline Soybean meal & Vietnam, India, USA, Argentina, Brazil & 22.5 & 20.7 & 35.0 & 53.0 \\
\hline Rice bran & Vietnam, Thailand, India & 22.0 & 21.9 & 7.5 & \\
\hline Rice meal & Vietnam, Thailand, India & 10.0 & 10.7 & & \\
\hline Wheat bran & China, India, Germany & 12.5 & 13.2 & 15.0 & 3.0 \\
\hline Cassava/tapioca & Vietnam, China, India & 19.0 & 18.0 & 12.5 & 13.0 \\
\hline Fish oil & Vietnam, China & 2.0 & 1.9 & & 1.0 \\
\hline Coconut meal & Philippines & & & 6.0 & \\
\hline Rape seed meal & India & & & 8.5 & \\
\hline Broken rice & Vietnam & & & 7.0 & \\
\hline Others & China, France, India, Taiwan, USA, Swiss & - & 0.7 & - & 4.0 \\
\hline
\end{tabular}


LCI data for diesel production and combustion came from Eco-Invent ${ }^{\circledR} 2$.0. The average transport distances of feed ingredients to the feed-manufacturing plant were $7,107 \mathrm{~km}$ for sea transport and $60 \mathrm{~km}$ for road transport. The transport distance of inputs to the farm was estimated at $100 \mathrm{~km}$ and was included in the farming process. On-farm diesel use ranged from close to 0 to $41 \mathrm{l} / \mathrm{t}$ fish, but as specified in Section 3.1, in the calculations an average of $51 / t$ fish was used.

Both the grow-out farms (see Table 2) and the feed-mills used electricity. We modelled electricity production and supply by adapting the Norwegian production and distribution network in EcoInvent ${ }^{\circledR} 2.0$ to the Vietnamese situation. Norway was used because it most resembled Vietnam in terms of its shape, energy source distribution and electricity supply grid. The energy sources used for electricity production (hydro-powered 20\%; diesel 50\%; gas $12 \%$; coal $18 \%$ ) were retrieved from the Vietnam Energy Information Administration (Anon 2007). We assumed that all electricity imported from neighbouring countries originated from hydro-powered plants. Moreover, we assumed that natural gas remained equally important after start-up of the new power plant in Ca Mau (An 2009) and that diesel remained important for the other existing or new plants in the Mekong Delta. On-farm electricity use varied from close to 1 to $108 \mathrm{kWh} / \mathrm{t}$ fish; the average of $41 \mathrm{kWh} / \mathrm{t}$ fish was used in the calculations.

\subsection{Chemical and medicine production}

After each production cycle the pond was emptied and sludge was removed. Sometimes the pond was flushed before starting a new production cycle, and lime and other products were sometimes applied before the pond was refilled with water. Most of the farmers used over $5 \mathrm{~kg}$ lime and roughly $1 \mathrm{~kg}$ of other products (mainly common salt, but also potentially harmful zeolite, chloride and coppersulphate) per ton fish produced. In addition to these pond preparation products, $0.27 \mathrm{~kg}$ vitamin $\mathrm{C}, 0.33 \mathrm{~kg}$ of products containing vitamins, enzymes and probiotics, and $0.15 \mathrm{~kg}$ medicines and antibiotics were used per ton fish produced.

To quantify the production of chlorides, lime, salt and zeolite, we used LCI data from EcoInvent ${ }^{\circledR 2}$ 2.0. The EcoInvent ${ }^{\circledR} 2.0$ database did not include the additional chemicals, probiotics, enzymes, medicines and vitamins applied. To quantify production of these products, we used LCI data on a similar production process, i.e. pesticide production.

\subsection{Water use and nutrient emissions}

Some of the superfluous feed and fish faeces flow out of the pond when refreshing water but most settle as solid waste on the pond bottom where sludge and sediment builds up. Sludge consists of the watery top-sediment on the pond bottom and is pumped to the river at least every 2 months during the grow-out phase and after harvesting. It also occasionally collected after harvest, to fertilise crops, but we neglected that in our LCA. The quantified nutrient discharge comprises exchanged pond water plus sludge discharge. Almost $80 \%$ of the farmers discharged sludge from their ponds during the grow-out cycle (Lam et al. 2009), but we assumed that all the sludge was discharged to the Mekong River.

We first checked the $\mathrm{N}$ balances to estimate total nutrient discharge and used that to estimate the discharge of other components. The FCR of 1.86 was used to estimate total waste. We calculated the $\mathrm{N}$ output on the basis of a dry matter content of $90 \%$ for feed and $30 \%$ for fish, and an $\mathrm{N}$ content of $22 \%$ for feed and $16 \%$ for fish. This resulted in a total $\mathrm{N}$ excretion of about $33 \mathrm{~kg} / \mathrm{t}$ fish. We did not distinguish between $\mathrm{N}$ from respiration and $\mathrm{N}$ from excretion, and for $\mathrm{N}$, we used the total $\mathrm{N}$ in the water column because the amounts of $\mathrm{N}$ from $\mathrm{N}_{2}, \mathrm{~N}_{2} \mathrm{O}, \mathrm{H}_{3} \mathrm{NO}_{3}$. $\mathrm{H}_{2} \mathrm{NO}_{2}, \mathrm{NH}_{4} \mathrm{OH}$ and $\mathrm{NH}_{3}$ in the water, sludge and sediments are not stable but vary according to the $\mathrm{pH}$ and the availability of oxygen. Consequently, if any $\mathrm{N}$ evaporated as $\mathrm{NH}_{3}, \mathrm{~N}_{2}$ or $\mathrm{N}_{2} \mathrm{O}$, its impact was not included in the assessment.

Dang (2007) monitored intensively farmed ponds in which the feed was derived from manure. During the 610 months of his observations, sediment volume and nutrient accumulation increased linearly with the amount of excreta applied. We used the equations in his Table 4 (Dang 2007) to quantify the nutrients retained in the bottom sediment (assuming that the accumulation of $\mathrm{N}$ and $\mathrm{P}$ in fish faeces from manure-fed ponds is similar to that in our pellet-fed ponds). The result was used to calculate total nutrient discharge from sludge.

Fish farmers in the Mekong Delta rely mainly on diurnal tidal fluctuations for water exchange, and $60 \%$ of them use a pump occasionally to supply refreshment water (Lam et
Table $4 \mathrm{~N}$ and $\mathrm{P}$ accumulation in sediment and sludge as calculated from total excreta and equations of Dang (2007)

\begin{tabular}{llll}
\hline Dependent variables & Predictive equations & $\mathrm{kg} \mathrm{ha}^{-1} \mathrm{year}^{-1}$ & Sediment kg/ton fish \\
\hline Total sediment $(\mathrm{TS})$ & $\mathrm{TS}=206+50^{*}$ Excreta & $1,248,000$ & 4,161 \\
$\mathrm{~N}\left(\mathrm{~N}_{\mathrm{ACC}}\right)$ & $N_{\mathrm{ACC}}=304+129^{*}$ Excreta & 3,220 & 10.7 \\
$\mathrm{P}\left(\mathrm{P}_{\mathrm{ACC}}\right)$ & $P_{\mathrm{ACC}}=89+58^{*}$ Excreta & 1,448 & 4.8 \\
\hline
\end{tabular}


al. 2009). Farmers reported opening the sluice gates 192 times during the grow-out phase and estimated the daily exchange rate to be $7 \%$ of pond volume. The nutrient output through refreshment water was calculated by subtracting the content of canal inlet water from the content of N, P, COD and TSS in the effluents discharged (Table 5). This led to a nutrient discharge that was four times that of the nutrient input from fish excrement estimated from the given FCRs. We recalculated nutrient discharge with a water use of $2,500 \mathrm{~m}^{3} / \mathrm{t}$ fish, i.e. one quarter of the quantity of refreshment water estimated by the farmers in the survey. This led to a discharge roughly equal to nutrient input, which is still high and thus a worst-case scenario.

The accumulated $\mathrm{N}$ and $\mathrm{P}$ discharges were 28.5 and $7.6 \mathrm{~kg} / \mathrm{t}$ fish, respectively.

\section{Results-impact assessment}

\subsection{Life cycle impact assessment (LCIA)}

Figure 3 summarises the LCIA results (calculated in SimaPro $\left.{ }^{\circledR}\right)$. Feed production was clearly the dominant contributor in almost all impact categories. Grow-out farming was the only other important process that with its nutrient discharge contributed the most to the impact categories eutrophication and FWET. The nutrient discharge from grow-out-farming was high but hardly modified river water quality compared with that before sector expansion (only $0.0005 \%$ of river water passes through the ponds, but this leads to a $0.01 \%$ increase of nutrients in river water).

The small but visible contribution from grow-out farming to HT was dominated by zeolite use and, to a lesser extent, by lime use. Grow-out farming dominated the total contribution to FWET, but its absolute contribution to FWET was much smaller than to HT and MAET (Table 7). However, HT cannot be compared with MAET and FWET on the basis of absolute contribution, as that would imply valuing them as equally important.

We analysed the impact data of individual farms by using hierarchical K-means clustering. This resulted in two clusters: one with seven farms scoring high and one with 21 farms scoring low on all impact categories. FCR was the only factor explaining why one cluster had more impact than the other $(P<0.05)$. No significant differences were identified for pond area, productivity or any other factor. This may be due to the high variation for some factors. Although not significant, the water exchange was also greater in the cluster with higher FCR.

The production of feed, i.e. ingredient production and transport and feed-milling, dominated almost all impact categories (see Fig. 3). We therefore looked more closely into the subsystem of feed production (Fig. 4). Rice bran was the major contributor to global warming and $\mathrm{AC}$ due to the quantity incorporated and the production of $\mathrm{N}$ and $\mathrm{P}$ fertilisers used and, to a lesser extent, due to the energy used for transport. Despite its relative modest share in total feed, wheat bran contributed the most to eutrophication due to a high level of nitrate emission during production. The contributions from fertiliser production and transport were much smaller. The contribution to the toxicity categories came mainly from the transport and energy processes related to the production of feed ingredients and more specifically from wheat bran, fishmeal and soybean. The main contribution to HT came from the emissions during production and use of fertiliser to produce feed ingredients, mainly fishmeal (24\%) and wheat bran (22\%), fuel $(20 \%)$ and electricity (16\%). The contribution to MAET from the feed came mainly from the electricity needed for the milling, fuel use for traction, production and transport (both marine and land); replacing the use of diesel for onfactory electricity generators by electricity from the grid reduced the impact by $25 \%$ and also reduced the contribution of electricity from $36 \%$ to $11 \%$.

\subsection{Assessment of water use and depletion}

Water depletion was estimated by simply totalling the water uses (Aubin 2008). The feed-mills and the striped catfish farmers both used two types of water: groundwater and surface water. The water withdrawal was either (a) consumed in the production process and thus lost for other

Table 5 Characteristics of inlet and discharge water, water of various pond types, waste water, sludge and pond sediment for aquaculture systems in SE Asia and the Mekong Delta

\begin{tabular}{|c|c|c|c|c|c|c|c|c|}
\hline & $\mathrm{P} / \mathrm{M}$ & Unit & BOD & COD & TAN & $\mathrm{NO}_{\mathrm{x}}$ & N-tot & P-tot \\
\hline Inlet water (Dang 2007) & $10 / 12$ & $\mathrm{mg} / \mathrm{l}$ & & & & & 3.5 & 0.26 \\
\hline Shallow pond water (Dang 2007) & $10 / 12$ & $\mathrm{mg} / \mathrm{l}$ & & 13.6 & & 0.08 & 7.1 & 1.0 \\
\hline Outlet water (Vu et al. 2008) & $9 / 3$ & $\mathrm{mg} / \mathrm{l}$ & 4.6 & 9.5 & 2.2 & 3.3 & 14.8 & 3.2 \\
\hline Refreshment water (Pham et al. 2010) & $4 / 5$ & $\mathrm{mg} / \mathrm{l}$ & 22 & 27 & 2.2 & - & 4.0 & 1.7 \\
\hline Waste water containing sludge (Pham et al. 2010) & $4 / 5$ & $\mathrm{mg} / \mathrm{l}$ & & 1769 & & & 45.6 & 22.7 \\
\hline
\end{tabular}

$P / M$ number of ponds/measurements, TAN total ammonia nitrogen, $\mathrm{NO}_{\mathrm{x}}=\mathrm{NO}_{2}+\mathrm{NO}_{3}$. 
Fig. 3 The average contribution to eight environmental impact categories from average feed production and from all other processes involved in the Pangasius farming

$$
\begin{aligned}
& \text { GW = Global warming; } \\
& \text { AC = Acidification; } \\
& \text { EU = Eutrophication; } \\
& \text { HT=Human Toxicity; }
\end{aligned}
$$

MAET=Marine Ecotoxicity;

FWET $=$ Fresh water Ecotoxicity.

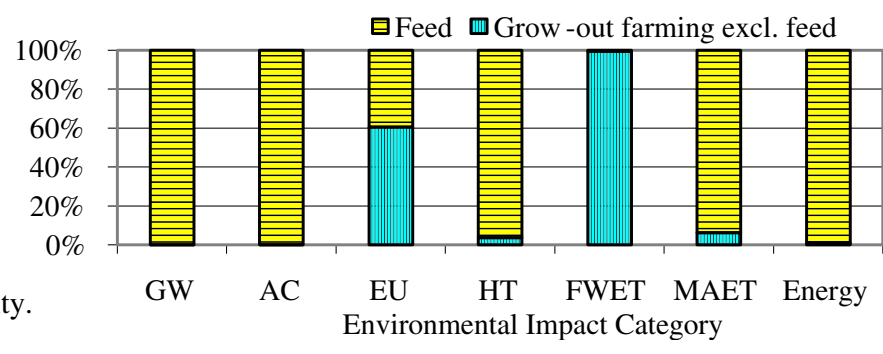

production processes, or (b) available after use for other processes (we assumed it was not polluted, i.e. was reusable). The water consumption is the water withdrawal minus the available water after use.

The average pond volume, based on dimensions given by farmers, was close to $130,000 \mathrm{~m}^{3}$. The lowest flow estimation of the Mekong River is $475,000 \mathrm{~km}^{3} /$ year (Hart et al. 2001). A refreshment rate of $2,500 \mathrm{~m}^{3}$ water per ton fish and a pond production of 1 million t/year catfish, means that about $0.0005 \%$ of river water is diverted through the ponds yearly.

Part of the water withdrawal is lost through evaporation and infiltration. Infiltration losses, i.e. vertical percolation plus lateral seepage, can be considered to be non-polluted available water. Evaporation losses in the tropical climate are 1,500 $\mathrm{mm} /$ year on average (Verdegem and Bosma 2009). This results in close to $180 \mathrm{~m}^{3} / \mathrm{t}$ fish for ponds producing $420 \mathrm{t} / \mathrm{ha}$ per year. Total feed-associated freshwater consumption of catfish was estimated at $3,472 \mathrm{~m}^{3} / \mathrm{t}$ fish (Verdegem and Bosma 2009). Thus, the total water consumption for striped catfish in the Mekong Delta can be estimated at about $6,150 \mathrm{~m}^{3} / \mathrm{t}$ fish.

\subsection{Assessment of flooding hazards}

The Mekong Delta in Vietnam covers close to $38,000 \mathrm{~km}^{2}$, of which $12,000 \mathrm{~km}^{2}$ is flooded in low flood years and $18,000 \mathrm{~km}^{2}$ in high flood years (Hien 1998). Pangasius ponds that are constructed near large streams for the convenience of water exchange and transportation occupy water storage capacity during flooding season. This endangers dikes and therefore increases the risk of flooding.

The area of ponds constructed on endiked land and right next to the dikes was $60 \mathrm{~km}^{2}$. This is less than $0.5 \%$ of the total area flooded in the Mekong Delta. Only $0.5 \%$ of pond area is located along $3.2 \mathrm{~km}$ of flood protection dikes classified as susceptible to erosion (Le et al. 2006).

\section{Discussion-interpretation}

\subsection{System boundaries}

This EIA had limited budget and time at its disposal and therefore focused on the main processes and impacts. Processes and impacts deemed to be less important or not relevant were excluded.

We did not have enough information to calculate nutrient discharge via the refreshment water of farms producing fish seed and fingerlings. However, this production process used less than $0.5 \%$ of inputs used for grow-out and was therefore considered negligible and excluded from this study to save time. Our decision to focus on the grow-out process is justified by the findings of other LCAs of aquaculture, e.g. on shrimp in Thailand (Mungkung 2005) and Pangasius in Indonesia (Aubin 2008). These studies confirm the low environmental impact of this production stage.

The stakeholders decided to exclude the fish-processing industry and retailing from the EIA as their focus was on setting priorities for reducing the environmental impact from fish farming systems. Inclusion of the processing and retailing, however, would have influenced the LCA results significantly. Mungkung (2005) showed that fish processing contributed greatly to eutrophication in an LCA of shrimp in Thailand. In a water quality assessment, Pham et al. (2010) reported that industrial processing of Pangasius fillets in Vietnam uses less than $1 \%$ of the total water
Fig. 4 The distribution of the contribution to six environmental impact categories of the inputs to the production process of the average feed. For abbreviations see Fig. 3
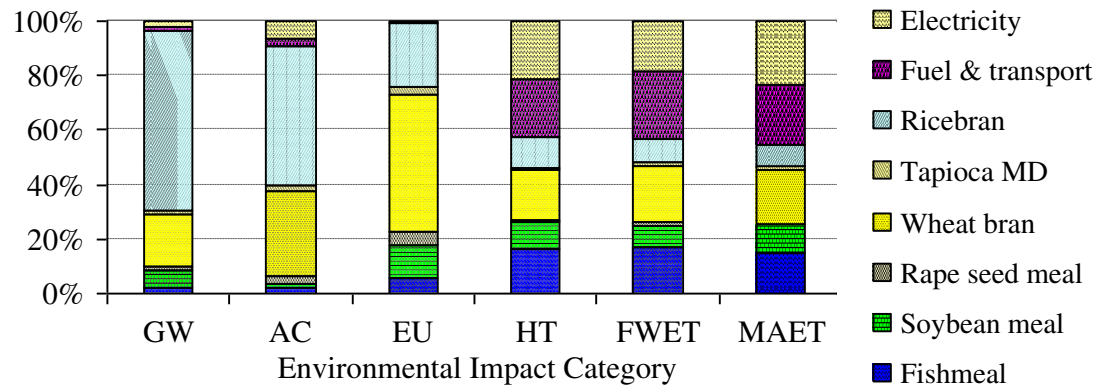
consumption up to the exit-gate of the grow-out farm. However, the nutrient discharge of processing based on Pham et al. (2010) is estimated at $16.5 \mathrm{~kg} \mathrm{~N}$ and $2 \mathrm{~kg}$ P per ton fish processed (the yield of fillet is close to $40 \%$ ). If processing had been included in the LCA reported in this paper, $\mathrm{N}$ output would have increased by about $60 \%$ and $\mathrm{P}$ output would have increased by about $25 \%$. The stakeholders with an interest in aquaculture EIAs and LCAs should be made aware of this and should consider including the processing in future EIAs and LCAs.

Emissions of $\mathrm{CO}_{2}, \mathrm{~N}_{2}, \mathrm{~N}_{2} \mathrm{O}, \mathrm{NH}_{3}$ and $\mathrm{CH}_{4}$ from the pond surface to the air were ignored because of the lack of sound data and because of the difficulties in quantifying these emissions (they depend on the $\mathrm{pH}$ and dissolved oxygen content of the pond and both fluctuate greatly). Emissions from rice paddies have been reported, but conditions at the deeper pond bottom are more anoxic (e.g. methane production might be higher if not absorbed in the water column). Research is needed to quantify the airborne emissions from Pangasius ponds.

Photochemical oxidant formation and ozone depletion were also ignored for the same reasons. Myrvang (2006) and Mungkung (2005), however, showed that some cradleto-gate processes contribute to these categories (e.g. through energy use, transport, chemicals and medicines). We may assume these impacts will reduce concomitantly with the mitigation of impacts on $\mathrm{GW}$ and various toxicity impacts.

\subsection{Evaluation of inventory results}

The quality of the LCI data for Pangasius grow-out and feed-milling which was elicited by the questionnaires is open to question. The samples surveyed may have been non-representative, and the assumptions about water exchange rate and nutrient mineralization in the sediment may not have been justified. Nevertheless, the survey yielded unique information. A possible shortcoming could have been that the government services were not wholly objective when they screened the data. It might have been advantageous to them to show with the data on water exchange that farmers respect their recommendations and to use favourable data on medicines use as this affects the exportability of the product. We adjusted water use to match the nutrient budget. The use of medicines was of minor importance for the impacts categories. Another survey checked the use of chemical and medicines in order to ascertain food safety (non-published data). Their results show that the substances and quantities used for Pangasius farming in the study area were not very different from those reported in our survey.

The nutrient outputs from the 28 ponds in our survey were based on their estimated daily discharges of water and on the average nutrient contents of outlet water and estimated sludge composition in the pond at the end of the production cycle for nine other ponds. To fit the nutrient balance, we assumed water refreshment at a rate of $2,500 \mathrm{~m}^{3} / \mathrm{t}$ fish, which is equivalent to replacing $0.4 \mathrm{~m}$ water column daily. Though such an assumption seems questionable, the results reported by Yakupitiyage et al. (2006) suggest that over $50 \%$ of the $\mathrm{P}$ and $\mathrm{N}$ from superfluous feed and faeces in semi-intensive tilapia ponds leave the pond through various processes (e.g. leaching, infiltration, immobilisation and mineralisation). These nutrients will be used by the vegetation and not contribute to any impact. Thus, leaving sludge in the ponds during the production cycle will decrease nutrient discharge and related impact categories such as eutrophication, since total suspended solids are reduced by sedimentation and mineralisation at the bottom. Consequently, leaving the sludge in place will reduce the amount of energy used for pumping and for the related impact categories, providing energy is not needed to aerate the pond for the air-breathing Pangasius.

The on-farm electricity use of $41 \mathrm{kWh} / \mathrm{t}$ fish was calculated from the information supplied by the 28 farms surveyed; the farms used also 51 fuel/t fish. A previous survey of four farms in An Giang found an electricity consumption of $217 \mathrm{kWh} / \mathrm{ha}$ of harvested fish (Pham 2008). Those farms hardly used the tide for daily water exchange and also pumped out sludge twice during the production cycle. Their electricity use would be more than $700 \mathrm{kWh} / \mathrm{t}$ fish, 18 times the figure from our 28 farms, assuming a harvest of 300 t/ha per crop. Only seven of the 28 farms in our survey regularly pumped for daily water exchange. The energy consumption for the 28 farms in our survey is based on real figures and considered the best available data. The survey by Pham (2008) was small, focused on farms pumping sludge, calculated electricity consumption from estimated pumping duration and pump capacity and ignored fuel consumption.

Our inventory supposed that $100 \%$ of the high-quality feed and $50 \%$ of the low-quality feed ingredients were imported. The recently published official figures for Vietnam, however, were $90 \%$ and $40 \%$ to $50 \%$, respectively. Using these figures in the calculations would slightly reduce the impacts from global transport, but increase the impacts within Vietnam.

Most of the inventory data for feed ingredient production came from EcoInvent ${ }^{\circledR} 2.0$. Insufficient time and means were available for us to check their reliability. However, other LCA studies have also shown that feed production dominates most of the impact categories (Papatryphon et al. 2004; Mungkung 2005; Aubin et al. 2009; Ayer and Tyedmers 2009). Those studies thus support our main findings. In common with most other studies, our screening 
study did not use region-specific data for feed ingredient production. We attributed all impacts from the processing of rice bran to the main product and the contribution of rice-bran to various impact categories is therefore slightly underestimated. Future research should preferably use specific inventory data for feed ingredient production and detail inventory data for feed-milling and feed ingredient production for each feed-mill separately. This would allow an LCA that explores the consequences of alternative feed ingredient production, transport and compositions (Pelletier and Tyedmers 2007). It would also enable sensitivity analyses to be done in combination with different scenarios for implementing proposed sediment management and nutrient recovery technologies in the Pangasius sector.

We analysed the environmental impact of different feeds of known composition generically. That is, generic impacts were calculated by using an average FCR and a typical feed composition not specifically related to any of the farms surveyed. Unfortunately, the data from our surveys did not enable us to account for the different feed brands used by individual farmers. When feed compositions and origin of feed ingredients were compared, however, we found different environmental impacts per ton striped catfish (Table 6). The influence of specific data is unclear, but we suspect it results in interesting differences (Pelletier et al. 2009), especially as the farm comparison in this study identified FCR as the factor causing higher impacts on seven of the 28 farms. We therefore advise carrying out an LCA with at least three different feed-mills, each using different feed ingredients and repeating surveys on farms using this feed.

\subsection{Evaluation of impact assessment results}

Our screening LCA omitted processes and impacts that stakeholders and team considered less important in the local context and used generic data for some processes. These were discussed above and are unlikely to influence our main finding. Since we used internationally accepted assessment methods, we also evaluate the quality of our LCIA as good. Table 7 compares our LCIA results with those from three other LCAs of finfish aquaculture. The similarities and differences are discussed below. By comparison with those LCAs, Pangasius farming contributes much more to global warming, acidification and HT. However, it is unlikely that our LCIA underestimated the impacts because we applied worst case scenarios where relevant.

The high FCR was the main reason that the contribution from Pangasius farming to most impact categories is greater than that from other fish culture systems (see Table 7). The contribution to global warming was comparable to that from Danish flatfish fisheries, which was approximately $10 \mathrm{t} \mathrm{CO}_{2}$ per ton fish (Thrane 2006). The contribution of Pangasius farming to eutrophication was similar to that of farming trout in flowthrough but was greater than that for salmon and rainbow trout. In all cases, the contribution to eutrophication was mainly from the emissions of various nitrogenous substances and, to a lesser extent, from phosphorous substances. The contribution of transport was limited (only $3 \%$ in the case of wheat bran). The emissions related to rice bran were lower because the soil in the paddies is almost permanently under water.

The contribution to any impact category of medicines and chemicals other than zeolite, lime and salt was limited. The environmental impact of most of the products used for pond preparation was mainly the result of their production and transport.

The methodology for biodiversity assessment in LCA is still weak (Curran et al. 2010), and this affects the relevance of results for related impact categories. We have therefore not reported in detail on land use, or on terrestrial and aquatic biodiversity. However, a few comments can be made in this context. The present biodiversity loss due to rice fields being converted into ponds is small because both types of land use have similarly small biodiversity. Land use changes and the effects of feed production on biodiversity were not included in the study. One of the

Table 6 The effect of feed composition on the environmental impact for relevant impact categories, according to ReCiPe-2008 (SimaPro $\left.{ }^{\circledR}\right)$ of producing of $1 \mathrm{~kg}$ of feed

\begin{tabular}{lccccccc}
\hline $\begin{array}{l}\text { Impact category } \\
\text { Feed source/unit }\end{array}$ & $\begin{array}{l}\mathrm{GW} \\
\mathrm{kg} \mathrm{CO} 2\end{array}$ & $\begin{array}{l}\mathrm{AC} \\
\mathrm{g} \mathrm{SO}^{2} \text {-eq }\end{array}$ & $\begin{array}{l}\mathrm{FWEU} \\
\mathrm{g} \mathrm{P}-\mathrm{eq}\end{array}$ & $\begin{array}{l}\mathrm{MAEU} \\
\mathrm{g} \mathrm{Neq}\end{array}$ & $\begin{array}{l}\mathrm{HT} \\
\mathrm{kg} \mathrm{DB} \text { eq }\end{array}$ & $\begin{array}{l}\text { MAET } \\
\mathrm{kg} \mathrm{DB} \text { eq }\end{array}$ & $\begin{array}{l}\text { Energy depletion } \\
\mathrm{kg} \text { oil eq }\end{array}$ \\
\hline $\mathrm{A}$ & 2.02 & 18.4 & 3.6 & 100.8 & 2.36 & 1.46 & 0.35 \\
$\mathrm{~B}-\mathrm{E}$ & 2.55 & 25.8 & 2.1 & 88.5 & 2.22 & 2.26 & 0.39 \\
$\mathrm{~F}$ & 2.54 & 25.3 & 2.3 & 88.4 & 2.19 & 1.27 & 0.39 \\
$\mathrm{G}$ & 0.98 & -14.1 & 5.3 & 3.2 & 2.38 & 1.51 & 0.2 .2 \\
\hline
\end{tabular}

FWEU Freshwater eutrophication, MAEU Marine eutrophication

For other abbreviations see Table 3 and Fig. 3 
Table 7 LCIA results for striped catfish production in the Mekong Delta (LCA-panga-MD) compared with results for four other farm-exit aquaculture LCIAs for main impact categories (all impacts per ton crop produced)

\begin{tabular}{|c|c|c|c|c|c|c|c|}
\hline LCIA (source) & $\begin{array}{l}\text { Impact category } \\
\text { Unit }\end{array}$ & $\begin{array}{l}\mathrm{GW} \\
\text { ton } \mathrm{CO}_{2}\end{array}$ & $\begin{array}{l}\mathrm{EU} \\
\mathrm{kg} \mathrm{PO}_{4}^{-} \text {eq }\end{array}$ & $\begin{array}{l}\mathrm{AC} \\
\mathrm{kgSO}_{2} \text {-eq }\end{array}$ & $\begin{array}{l}\mathrm{HT} \\
\mathrm{Kg} \text { DB eq }\end{array}$ & $\begin{array}{l}\text { MAET } \\
\text { t DB eq }\end{array}$ & $\begin{array}{l}\text { Energy } \\
\text { GJ }\end{array}$ \\
\hline Pangasius, MD & & 8.93 & $65^{\mathrm{a}}$ & 48.1 & 4,280 & 2,512 & 13.2 \\
\hline Salmon, flow-though (Ayer and Tyedmers 2009) & & 5.04 & 31 & 33.3 & 2,570 & 3,840 & 132 \\
\hline Trout flow-through (Aubin et al. 2009) & & 2.75 & 66 & 19.2 & - & - & 78 \\
\hline Rainbow trout, flow-through (Papatryphon et al. 2004) & & 1.3 & 44 & 6.7 & - & - & 21 \\
\hline
\end{tabular}

For the abbreviation see Fig. 3 and Table 6

En dash data not available

${ }^{\text {a }}$ From CML2 to be able to compare with others

impacts of the use of soybean may be on deforestation (e.g. in Brazil). Aquatic biodiversity may be affected through pond effluents and is expected to be influenced by using caught fish for feed. We recommend including the effect of feed ingredient production on land use and biodiversity (both aquatic and terrestrial) in future LCAs. Obviously, this presupposes that appropriate methodology is available.

Total water use for the production of striped catfish was estimated at $6,150 \mathrm{~m}^{3} / \mathrm{t}$ fish, which is about $150 \%$ of water needed for the production of pork (Verdegem et al. 2006). Though not a main contributor to total water use, evaporation in the Mekong delta (approx. 1,200 mm/year) is lower than the average $(1,500 \mathrm{~mm} /$ year $)$ assumed by Verdegem and Bosma (2009). The water withdrawal from the river is the main contributor to water loss, and the volume considered here represents the lower range found by Lam et al. (2009), and in a recent study which effectively measured daily water refreshment during the production cycle (Van der Heijden et al. 2011). However, given the total river water flow, water withdrawal from the Mekong River is not the main concern; water is the carrier of discharged nutrients, and we estimated these quantities carefully, using a nutrient balance approach. Current fishfarming practice does not guarantee good water quality. If the FCR is improved, however, water use could be halved and this would not only reduce feed-related water use but also the need to refresh water (Bosma and Verdegem 2011). Water consumption could be further reduced by using the effluent water to irrigate rice or other crops.

\subsection{Options for mitigation}

The overall quality of our LCA enables us to identify two critical processes for mitigating the environmental impact from Pangasius production. These are feed production (i.e. feed ingredient production, transport and feed-milling) and grow-out farming.

Feed-ingredient production, transport and milling are predominantly responsible for impacts on GW, HT and
MAET and also contribute to $50 \%$ of the eutrophication. Pond effluent contributes the other $50 \%$ to eutrophication and also causes FWET and other water quality problems in canals and rivers. All of these impacts can be addressed by improving feed use efficiency through better feed formulation and pond management (Bosma and Verdegem 2011). In particular, the inclusion of rice bran, a low-quality feed, decreases efficiency and increases the impact on categories such as EU and FWET. Replacing locally produced rice bran by feed ingredients from elsewhere may affect most impact categories (Pelletier and Tyedmers 2007). This should be assessed by means of a sensitivity analysis and region-specific inventory. Pond effluent should also be studied further in relation to mitigation strategies (e.g., its use for irrigation, or the possibility for recovering $\mathrm{N}$ and $\mathrm{P}$ as struvite).

\section{Conclusions}

The feed ingredient production, which largely took place outside Vietnam, dominated most of the impacts in the LCA except for eutrophication and FWET. Of the feed ingredients, rice bran contributed the most to global warming and acidification, mainly due to the quantity used, while wheat bran contributed the most to eutrophication, mainly through emissions during production. The production of fishmeal, soybean and wheat bran, transport and energy processes were the most important contributors to MAET. Grow-out farming in Vietnam contributed the most to eutrophication and FWET. The water nutrient discharge was high, but it hardly modified river water quality compared with that before sector expansion. Environmental impacts can be reduced by effectively managing sludge and by using feeds with a lower FCR and less fishery product in the feed. Further research is needed into possible FCR reductions through modifying feed composition and ingredient sources. 
Acknowledgements We thank the Vietnamese study team, feedmilling companies, farmers, Sustainable Fisheries Partnership, the College of Aquaculture and Fisheries of Can Tho University and Michiel Fransen for their contribution to data collection and analysis. We acknowledge financial and administrative support by the Vietnamese Ministry of Agriculture and Rural Development and Dutch ministry for Agriculture, Nature and Food Safety.

Open Access This article is distributed under the terms of the Creative Commons Attribution Noncommercial License which permits any noncommercial use, distribution, and reproduction in any medium, provided the original author(s) and source are credited.

\section{References}

An M (2009) Energy for the Mekong Delta

Anon (2007) Country analysis briefs. Energy Information Administration, Vietnam

Aubin (2008) Person. commun.

Aubin J, Papatryphon E, van der Werf HMG, Chatzifotis S (2009) Assessment of the environmental impact of carnivorous finfish production systems using life cycle assessment (The Sustainability of Seafood Production and Consumption). J Clean Prod 17 (3):354-361

Ayer NW, Tyedmers PH (2009) Assessing alternative aquaculture technologies: life cycle assessment of salmonid culture systems in Canada (The Sustainability of Seafood Production and Consumption). J Clean Prod 17(3):362-373

Bartley DM, Brugère C, Soto D, Gerber P, Harvey B (eds) (2007) Comparative assessment of the environmental costs of aquaculture and other food production sectors: methods for meaningful comparisons. FAO/WFT Expert Workshop. 24-28 April 2006, Vancouver, Canada. FAO Fisheries Proc., vol 10. FAO

Bosma RH, Verdegem MCJ (2011) Sustainable aquaculture in ponds: principles, practices and limits. Livest Sci 139(1-2):58-68

Bush S, Khiem NT, Sinh LX (2009) Governing the environmental and social dimensions of pangasius production in Vietnam: a review. Aquac Econ Manag 13:271-293

Christiansen K (ed) (1997) Simplifying LCA: just a cut? Society of Environmental Toxicology and Chemistry (SETAC). Brussels, Belgium

Curran M, de Baan L, De Schryver AM, van Zelm R, Hellweg S, Koellner T, Sonnemann G, Huijbregts MAJ (2010) Toward meaningful end points of biodiversity in life cycle assessment $\dagger$. Environ Sci Technol 45(1):70-79

Dang KN (2007) The role of a fish pond in optimizing nutrient flows in integrated agriculture-aquaculture farming systems. Chapter 5. $\mathrm{PhD}$, Wageningen University, Wageningen, $\mathrm{p} 112$

FAO (1972) Food Composition Table for Use in East Asia. U. S. Department of Health, Education and Welfare, and FAO' Food Policy and Nutrition Division

Goedkoop M, Schryver AD, Oele M (2008) Introduction to LCA with SimaPro 7. Pré Consultants. http://www.pre.nl/simapro/manuals/. 2009

Guinée J (ed) (2002) Handbook on Life Cycle Assessment. Operational Guide to the ISO Standards. ISBN 1-4020-0228-9 (HB)/ ISBN 1-4040-0557-1 (PB). Kluwer AP, Dordrecht

Hart BT, Jones MJ, Pistine G (2001) Transboundary water quality issues in the Mekong River Basin. MRC Vientiane, Laos

Hauschild MZ (2008) Person. commun.

Hauschild MZ, Potting J (2005) Spatial differentiation in Life Cycle impact assessment - The EDIP2003 Method Environ news, vol 80. Danish EPA, Copenhagen
Hauschild MZ, Wenzel H (1998) Stratospheric ozone depletion as criterion in the environmental assessment of products. In: Hauschild MZ, Wenzel H (eds) Environmental Assessment of Products, vol 2: Scientific Background. Springer, p 584

Hien NX (1998) Hydraulic modelling and flood control planning in the Mekong Delta Paper presented at the Regional Workshop: Flood management and mitigation in the Mekong River Basin. LAO PDR, Vientiane

ISO (2006) Environmental management - Life Cycle Assessment Requirements and Guidelines. ISO

Lam PT, Bui TM, Nguyen TTT, Gooley GJ, Ingram BA, Nguyen PT, Nguyen HV, DeSilva SS (2009) Current status of farming practices of striped catfish, Pangasianodon hypophthalmus, in the Mekong Delta Vietnam. Aquac 296:227-236

Le MH, Hitoshi T, Nguyen TT, Nguyen TV (2006) Prediction of river bank erosion in the lower Mekong river delta. Paper presented at the Vietnam-Japan Estuary workshop, Hanoi, Vietnam, 22-24 August 2006

Mungkung R (2005) Shrimp Aquaculture in Thailand: Application of Life Cycle Assessment to Support Sustainable Development. $\mathrm{PhD}$, University of Surrey

Myrvang M (2006) Life cycle assessment of a marine farm co-located with a refinery. MSc-thesis, Norwegian University of Science and Technology

Nguyen PT, Dang THO, Nguyen TA (2008) Striped catfish (Pangasianodon hypophthalmus) aquaculture in Viet Nam: an unprecedented development within a decade. In: Nguyen PT (ed) Catfish Aquaculture in Asia, Can Tho, Vietnam. Can Tho University, Vietnam

Nhi TV (2005) The use of local feedstuffs in diets for Tra catfish (Pangasianodon hypophthalmus) cultured in cages in An Giang Province. Msc, Can Tho University, Vietnam

Papatryphon E, Petit J, Kaushik SJ, Werf HMGvd (2004) Environmental impact assessment of salmonid feeds using life cycle assessment (LCA). Ambio 33(6):316-323

Pelletier N, Tyedmers P (2007) Feeding farmed salmon: Is organic better? Aquac 272(1-74):399-416

Pelletier NL, Ayer NW, Tyedmers PH, Kruse SA, Flysjo A, Robillard G, Ziegler F, Scholz AJ, Sonesson U (2007) Impact categories for life cycle assessment research of seafood production systems: review and prospectus. Int J Life Cycle Assess 12(6):414-421

Pelletier N, Tyedmers P, Sonesson U, Scholz A, Ziegler F, Flysjo A, Kruse S, Cancino B, Silverman H (2009) Not all aalmon are created equal: life cycle assessment (LCA) of global salmon farming systems. Environ Sci Technol 43(23):8730-8736

Pham AT (2008) Person. commun.

Pham AT, Kroeze C, Mol A, Bush S (2010) Water pollution by Pangasius production in the Mekong Delta, Vietnam: causes and options for control. Aquac Res 42(1):108-128

Phong LT, Boer IJMD, Udo HMJ (2011) Life cycle assessment of food production in integrated agriculture-aquaculture systems of the Mekong Delta. Livest Sci 139(1-2):22-29

Rosenbaum RK, Bachmann TM, Hauschild MZ, Huijbregts MAJ, Jolliet O, Juraske R, Köhler A, Larsen HF, MacLeod M, Margni M, McKone TE, Payet J, Schuhmacher M, Dvd M (2008) USEtox-The UNEP-SETAC toxicity model: recommended characterisation factors for human toxicity and freshwater ecotoxicity in Life Cycle Impact Assessment. Int J Life Cycle Assess 13(7):532-546

Thrane M (2006) LCA of Danish fish products, new methods and insights. Int J Life Cycle Assess 11(1):66-74

Todd JA, Curran MA (1999) Streamlined Life-Cycle Assessment: A Final Report from the SETAC North America Streamlined LCA Workgroup. Society of Environmental Toxicology and Chemistry

Van der Heijden PGM, Poelman M, Vo MS, Nhut L, Bosma RH (2011) Monitoring Quantity and Quality of Pangasius pond effluent. 
Report of project BO71070107116, Reliable and measurable standards for emissions in aquaculture. Centre for Development Innovation, Wageningen University \& Research

Verdegem MCJ, Bosma RH (2009) Water withdrawal for brackish and inland aquaculture and options to produce more fish in ponds with present water use. Water Policy 11(Supplement 1):52-68

Verdegem MCJ, Bosma RH, Verreth JAV (2006) Reducing water use for animal production through aquaculture. Water Resour Dev 22 (1):101-113

$\mathrm{Vu}$ UN, Huynh GT, Thanh PTN (2008) Fluctuation of water quality in catfish (Pangasianodon hypophthalmus) ponds referring to seasons and fish health status. In: Phung PT (ed) Int. Conf. Catfish aquaculture in Asia, Can Tho city, Vietnam. Can Tho University, VietNam, p 109

Weidema BP, Wesnæs MS (1996) Data quality management for life cycle inventories - an example of using data quality indicators. J Clean Prod 4(3-4):167-174

Yakupitiyage A, Ranamukhaarachchi SL, Yi Y, Mizanur R (2006) Nutrient accumulation in Tilapia pond sediment and its agricultural uses. In: Zijpp AJvd, Verreth JAJ, Tri LQ et al (eds) Fish Ponds in Farming Systems. Wageningen Acad. Publ, Wageningen, pp 89-96 